\title{
STUDY OF INFECTION OF EXTERNAL PARASITES OF FISH Cyprinus carpio COVERED INFLOATING CAGES ON THE RIVER EUPHRATES- DHI QAR
}

\author{
${ }^{1}$ BASEM AKOOL ALI AL-SAHLANY \\ ${ }^{2}$ DR. BASHAR ABDUL-HUSSAIN ELLEWI AL-SA'ADI \\ ${ }^{3}$ DR.KAMIL K.FAHAD
}

\begin{abstract}
Morbidity rate with severity of infection was recorded in 405 carp fish ,124 in the first station,143 in the station and 138 in the third station in the fish laboratory in college of Agriculture, theqar university, The results revealed presence of 14 type of external parasites,tow types of them are recorded at the first time in carp fish in Iraq asahost for which, included asingle type of protozoa which carry cilia (Ichthyophthirius multifiliis Fouquet, 1876). the study recorded 13 type of monogenodea of single origin and it was noticed appositive relationship between water temperature and the increased of morbidity rate and severity of infection by some external parasite but there was a reverse relation between the increased concentration of dissolved salts and morbidity and severity of infection with parasites and it was significant $1(p<0.01)$ during the studied period.
\end{abstract}

\section{Introduction}

Fisheries represent one of the important aspects of national development in Iraq, with a vast water area of about 1.1 million hectares, represented by the Tigris and Euphrates and its tributaries, marshes and lakes as well as fish farms. As an important source of animal proteins and one of the main pillars of the production base in livestock, which is increasing demand, and conservation and development of food security strategies. In view of the significant advantages of fish farming, the importance of fish farming has been significant over the past years because of high protein quality of human health (3). The nutritional value of meat fish is high because it contains proteins and fats at high rates in addition to the vitamins necessary for human health of the two types of dissolved in fat, such as vitamins E.E. D3 and dissolved in water such as C vitamins. B12. B1 also contains minerals such as calcium and phosphorus and the essential amino acids of the human body that cannot be installed inside and must be obtained with food 
such as Arginine Valine, Histidine and others (4). Carp fish have the greatest interest in the world because of its advantages such as resistance to environmental fluctuations, rapid growth and consumerism, as well as the ease of breeding and the availability of food requirements ( 5 and 6). In recent years, fish farming projects in Iraq have spread widely, whether in floating cages or ponds due to the decline in natural water production due to pollution and overfishing. Therefore, fish culture in floating cages is one of the important solutions to increase fish production. The diseases that affect the fish are divided into two categories, which include, first, communicable diseases, including fungal, viral, bacterial and parasitic diseases. Second, noncommunicable diseases also include genetic diseases, environmental food shortages and tumors (9). The parasitic diseases of fish are widely considered to be the most common disease among fish diseases. The main source of most pathogens is parasites, which cause secondary infections such as viruses, fungi and bacteria, which in turn cause extensive economic losses10)). He also pointed out that the economic losses are due to the loss of growth and the losses caused by diseases of the external parasites of fish, especially in the cases of dense. As well as in $80 \%$ of diseases that affect fish are parasitic diseases especially in warm water fish (12).

\section{Materials and Methods:}

Fish samples were collected two to three times a week from the specific study areas and from floating cages. During the research period from July 2017 to the end of June 2018, samples were taken randomly by the network used by floating cages. Then put directly in a 500 liter plastic basin. Each fish was examined and examined for large external parasites with the naked eye first and then a dissecting microscope (XSZ_107T) was used. The size of the infection was determined on the basis of the percentage of dividing the number of fish affected by a parasite by the number of fish examined during a certain period. The severity of the infection was calculated on the basis of the number of parasites divided by the number of infected fish during a certain period.

\section{Statistical analysis:}

The Statistical Analysis System (13) was used to analyze the effect of the months of the year and the station in the studied traits. The differences between the mean and the least significant difference were measured.

\section{Results and discussion:}


The parasitic animal group was identified by the common carp (Cyprinids1carpio) during the duration of the study and determined the proportion and severity of the infection. Monogenoidea was one species of Dogielius, seven species of Dactylogyrus, two species of Gyrodactylus and a genus of both the Diplozoon and Eudiplozoon species. As well as one kind of genus. Discocotyle

Primary cilia holder Ichthyophthirius multifiliis Fouquet, 1876

Monophysite Gyrodactylus elegans von Nordmann, 1832

Parasite monoclonal Dactylogyrus vastator Nybelin, 1924

Monoclonal parasite Dactylogyrus minutus Kulwiec, 1927

Dactylogyrus extensus Mueller \& Van Cleave, 1932

Monophosphaceous parasite Diplozoon paradoxum von Nordmann, 1832

Monoclonal parasite Discocotyle sagittata Leuckart, 1842

The Dogielius persicus Molnár et Jalali, 1992

Phyto Gyrodactylus markevitschi Kulakovskaya, 1952

Dactylogyrus dogieli Gusev, 1953

Dactylogyrus simplex Bychowsky, 1936

For the Dactylogyrus achmerowi Gussev, 1955

Dactylogyrus arqcatus Yamaguti, 1942

Groove Khotenovsky, 1985 Eudiplozoon nipponicum (Goto, 1891)

The results of the current study showed the incidence of the common carp in these types of parasites in the three stations. The parasite infection showed clear monthly changes, which increased both the incidence and severity of the disease and in accordance with the gradual rise in temperature as shown in Table 1, 2, 3. Table (1) shows the percentage and severity of infection in the first station, which recorded the highest infection rate of $87.5 \%$ during the month of June to the parasite Discocotyle sagittata if not recorded on the fish of the common carp previously and thus is a record for the first time on the carp common as a new host in Iraq. The lowest dose of the first $2 \%$ was recorded in Dactylogyrus extensus during the month of November. The highest level of infection of the first station 22 of the parasite Diplozoon paradoxum during the month of December. As shown in Table (2) the percentage and severity of infection in the second station during the study period, which recorded the highest rate of infection of $58.33 \%$ during the month of June to the parasite Diplozoon paradoxum. The lowest dose of the first station was $\mathbf{7 . 1 4 \%}$ for Dactylogyrus achmerowi during December. The highest severity was recorded for 
the second station (Dactylogyrus dogieli) in December. Table (3) shows the proportion and severity of infection in the third station, which recorded the highest infection rate of $81.81 \%$ during the month of June for the parasite Discocotyle sagittata. The lowest incidence of the third station was $8.33 \%$ for Dactylogyrus minutus and during December. The highest severity was recorded for the third station 21 of the Diplozoon paradoxum parasite. During the first month of Ramadan, while the severity and the rate of injury in some months for the three stations was not. The study showed the incidence of common carp in the parasite Dogielius persicus Molnár et Jalali, 1992. Thus, the common carp is a new host for the first time in Iraq in addition to the species mentioned earlier. The results of the statistical analysis showed significant differences in the incidence of normal carp fish in the three stations at a potential level $(p<0\rangle$ 05). Temperature is an important environmental factor of the aquatic environment. 26 The changes in temperature of water affect the growth of larvae (28). The temperature of water is one of the most important factors in clarifying changes in parasitic infection intensity in fish 
ISSN Onlin:2708-9347, ISSN Print: 2708-9339 Volume 9, Issue 1 (2020) PP 1-12

https://jam.utq.edu.iq/index.php/main $\quad$ Doi: https://doi.org/10.54174/UTJagr.Vo9.N1./01

Table 1. The incidence and severity of infection in the first station according to the different months of the study

\begin{tabular}{|c|c|c|c|c|c|c|c|c|c|c|c|c|c|}
\hline \multirow[t]{3}{*}{ قيمة LSD } & \multicolumn{12}{|c|}{$\begin{array}{l}\text { Injury rate and severity in the first station in the months of the study (the upper row represents the percentage of injury and } \\
\text { the lower row represents the severity of the injury }\end{array}$} & \multirow[b]{3}{*}{ Parasite name } \\
\hline & \multicolumn{12}{|c|}{ (الاشهز } & \\
\hline & 6 & 5 & 4 & 3 & 2 & 1 & 12 & 11 & 10 & 9 & 8 & 7 & \\
\hline${ }^{*} 5.38$ & 11.16 & 16.25 & 5.00 & 0.00 & 0.00 & 0.00 & 22.00 & 18.00 & 4.00 & 0.00 & 12.80 & 14.60 & D. paradoxum \\
\hline${ }^{*} 14.79$ & 0.00 & 0.00 & 0.00 & 0.00 & 0.00 & 0.00 & 16.70 & 6.50 & 0.00 & 28.50 & 36.40 & 62.50 & \multirow{2}{*}{ G. markewitschi } \\
\hline *6.33 & 0.00 & 0.00 & 0.00 & 0.00 & 0.00 & 0.00 & 2.00 & 2.00 & 0.00 & 18.50 & 17.00 & 7.20 & \\
\hline *22.63 & 87.50 & 0.00 & 0.00 & 0.00 & 0.00 & 0.00 & 8.10 & 0.00 & 20.00 & 42.90 & 54.50 & 0.00 & \multirow{2}{*}{ D. sagittata } \\
\hline${ }^{*} 4.98$ & 11.14 & 0.00 & 0.00 & 0.00 & 0.00 & 0.00 & 18.00 & 0.00 & 6.50 & 13.60 & 9.60 & 0.00 & \\
\hline${ }^{*} 14.58$ & 0.00 & 0.00 & 0.00 & 0.00 & 0.00 & 0.00 & 0.00 & 0.00 & 0.00 & 42.90 & 45.50 & 0.00 & \multirow{2}{*}{ D. simplex } \\
\hline${ }^{*} 5.09$ & 0.00 & 0.00 & 0.00 & 0.00 & 0.00 & 0.00 & 0.00 & 0.00 & 0.00 & 15.00 & 8.60 & 0.00 & \\
\hline * 19.26 & 75.00 & 66.67 & 54.55 & 30.76 & 8.30 & 14.28 & 8.10 & 22.20 & 30.00 & 28.50 & 36.40 & 0.00 & \multirow{2}{*}{ D. vastator } \\
\hline${ }^{*} 7.38$ & 11.66 & 9.16 & 5.50 & 5.50 & 2.00 & 2.00 & 15.00 & 9.50 & 7.30 & 17.00 & 17.70 & 0.00 & \\
\hline${ }^{\star} 12.28$ & 0.00 & 0.00 & 0.00 & 0.00 & 0.00 & 0.00 & 16.70 & 11.10 & 40.00 & 0.00 & 0.00 & 0.00 & \multirow{2}{*}{ I. multifiliis } \\
\hline NS & 0.00 & 0.00 & 0.00 & 0.00 & 0.00 & 0.00 & 2.50 & 2.00 & 0.50 & 0.00 & 0.00 & 0.00 & \\
\hline${ }^{*} 18.51$ & 0.00 & 55.55 & 36.36 & 38.46 & 8.30 & 7.14 & 8.30 & 2.00 & 30.00 & 0.00 & 0.00 & 0.00 & \multirow{2}{*}{$\begin{array}{c}D \\
\text {.extensus }\end{array}$} \\
\hline${ }^{*} 5.79$ & 0.00 & 13.40 & 6.50 & 2.40 & 3.00 & 2.00 & 3.00 & 1.00 & 6.00 & 0.00 & 0.00 & 0.00 & \\
\hline * 16.64 & 50.00 & 66.67 & 36.36 & 0.00 & 0.00 & 0.00 & 0.00 & 0.00 & 0.00 & 0.00 & 0.00 & 0.00 & \multirow{2}{*}{$\begin{array}{l}\text { Gyrodactylus } \\
\text { elegans }\end{array}$} \\
\hline${ }^{*} 6.39$ & 15.50 & 4.66 & 4.50 & 0.00 & 0.00 & 0.00 & 0.00 & 0.00 & 0.00 & 0.00 & 0.00 & 0.00 & \\
\hline * 19.50 & 62.50 & 66.67 & 0.00 & 0.00 & 0.00 & 0.00 & 0.00 & 0.00 & 0.00 & 0.00 & 0.00 & 0.00 & \multirow{2}{*}{$\begin{array}{l}\text { Dogielius } \\
\text { persicus }\end{array}$} \\
\hline${ }^{*} 5.08$ & 14.60 & 5.50 & 0.00 & 0.00 & 0.00 & 0.00 & 0.00 & 0.00 & 0.00 & 0.00 & 0.00 & 0.00 & \\
\hline
\end{tabular}


ISSN Onlin:2708-9347, ISSN Print: 2708-9339 Volume 9, Issue 1 (2020) PP 1-12

https://jam.utq.edu.iq/index.php/main $\quad$ Doi: https://doi.org/10.54174/UTJagr.Vo9.N1./01

\begin{tabular}{|c||c||c||c||c||c||c||c||c||c||c||c||c||c||c||c||c|}
\hline${ }^{*} 18.72$ & 0.00 & 55.55 & 0.00 & 0.00 & 0.00 & 0.00 & 0.00 & 0.00 & 0.00 & 0.00 & 0.00 & 0.00 & Dactylogyrus \\
\hline${ }^{*} 4.25$ & 0.00 & 6.00 & 0.00 & 0.00 & 0.00 & 0.00 & 0.00 & 0.00 & 0.00 & 0.00 & 0.00 & 0.00 & arquatus \\
\hline${ }^{*} 16.37$ & 0.00 & 44.44 & 0.00 & 0.00 & 0.00 & 0.00 & 0.00 & 0.00 & 0.00 & 0.00 & 0.00 & 0.00 & Eudiplozoon \\
\hline${ }^{*} 5.69$ & 0.00 & 14.50 & 0.00 & 0.00 & 0.00 & 0.00 & 0.00 & 0.00 & 0.00 & 0.00 & 0.00 & 0.00 & nipponicum \\
\hline
\end{tabular}


Table 2. The incidence and severity of infection in the second station according to the different months of the study

\begin{tabular}{|c|c|c|c|c|c|c|c|c|c|c|c|c|c|}
\hline \multirow[t]{3}{*}{ قيمة } & \multicolumn{12}{|c|}{$\begin{array}{l}\text { Injury rate and severity in the second station in the months of the study (the top row represents the percentage of injury and the } \\
\text { (bottom row represents the severity of injury }\end{array}$} & \multirow[t]{3}{*}{ Parasite name } \\
\hline & \multicolumn{12}{|c|}{ الاشهز } & \\
\hline & 6 & 5 & 4 & 3 & 2 & 1 & 12 & 11 & 10 & 9 & 8 & 7 & \\
\hline * 21.75 & 54.54 & 45.45 & 66.66 & 12.50 & 0.00 & 0.00 & 20.00 & 23.00 & 12.50 & 0.00 & 58.33 & 57.14 & \multirow{2}{*}{ D. paradoxum } \\
\hline * 4.83 & 9.33 & 9.40 & 4.50 & 21.00 & 0.00 & 0.00 & 9.00 & 4.66 & 4.00 & 0.00 & 9.85 & 7.75 & \\
\hline * 17.45 & 0.00 & 0.00 & 0.00 & 0.00 & 0.00 & 0.00 & 20.00 & 0.00 & 0.00 & 46.15 & 41.66 & 0.00 & \multirow{2}{*}{ G. markewitschi } \\
\hline * 5.71 & 0.00 & 0.00 & 0.00 & 0.00 & 0.00 & 0.00 & 2.50 & 0.00 & 0.00 & 6.33 & 15.20 & 0.00 & \\
\hline * 19.42 & 72.72 & 0.00 & 0.00 & 0.00 & 0.00 & 8.33 & 10.00 & 15.30 & 0.00 & 0.00 & 58.33 & 50.00 & \multirow{2}{*}{ D. dogieli } \\
\hline${ }^{*} 5.63$ & 9.12 & 0.00 & 0.00 & 0.00 & 0.00 & 7.00 & 23.00 & 6.00 & 0.00 & 0.00 & 8.14 & 6.85 & \\
\hline * 22.79 & 81.81 & 0.00 & 0.00 & 0.00 & 0.00 & 0.00 & 0.00 & 0.00 & 18.75 & 53.84 & 50.00 & 42.85 & \multirow{2}{*}{ D. sagittata } \\
\hline * 5.16 & 7.22 & 0.00 & 0.00 & 0.00 & 0.00 & 0.00 & 0.00 & 0.00 & 3.00 & 7.42 & 12.33 & 12.16 & \\
\hline * 18.30 & 0.00 & 0.00 & 0.00 & 0.00 & 0.00 & 0.00 & 0.00 & 0.00 & 18.75 & 61.50 & 66.66 & 0.00 & \multirow{2}{*}{ D. simplex } \\
\hline * 5.74 & 0.00 & 0.00 & 0.00 & 0.00 & 0.00 & 0.00 & 0.00 & 0.00 & 4.66 & 7.00 & 10.25 & 0.00 & \\
\hline * 20.55 & 45.45 & 54.00 & 25.00 & 25.00 & 18.18 & 8.33 & 10.00 & 15.30 & 0.00 & 0.00 & 0.00 & 42.85 & \multirow{2}{*}{ D. vastator } \\
\hline * 6.26 & 9.60 & 9.33 & 10.00 & 6.00 & 6.00 & 5.00 & 13.00 & 8.20 & 0.00 & 0.00 & 0.00 & 11.33 & \\
\hline * 17.04 & 0.00 & 36.36 & 33.33 & 50.00 & 0.00 & 0.00 & 10.00 & 15.30 & 18.75 & 30.76 & 0.00 & 0.00 & \multirow{2}{*}{ D. achmerowi } \\
\hline${ }^{*} 5.61$ & 0.00 & 10.25 & 11.50 & 4.50 & 0.00 & 0.00 & 15.00 & 5.50 & 9.00 & 9.00 & 0.00 & 0.00 & \\
\hline * 17.83 & 0.00 & 0.00 & 0.00 & 0.00 & 9.00 & 8.33 & 0.00 & 7.69 & 0.00 & 30.76 & 0.00 & 0.00 & \multirow{2}{*}{ D. minutes } \\
\hline * 4.79 & 0.00 & 0.00 & 0.00 & 0.00 & 9.00 & 4.00 & 0.00 & 6.00 & 0.00 & 8.33 & 0.00 & 0.00 & \\
\hline * 16.38 & 0.00 & 0.00 & 0.00 & 0.00 & 0.00 & 0.00 & 10.00 & 0.00 & 12.50 & 30.76 & 0.00 & 0.00 & \multirow{2}{*}{ I. multifiliis } \\
\hline * 5.94 & 0.00 & 0.00 & 0.00 & 0.00 & 0.00 & 0.00 & 6.00 & 0.00 & 4.50 & 10.50 & 0.00 & 0.00 & \\
\hline * 21.26 & 0.00 & 54.00 & 50.00 & 37.50 & 9.00 & 16.66 & 0.00 & 0.00 & 18.75 & 0.00 & 0.00 & 0.00 & \multirow{2}{*}{$\begin{array}{c}\text { D } \\
\text { extensus }\end{array}$} \\
\hline * 5.72 & 0.00 & 11.16 & 9.16 & 5.00 & 8.00 & 2.50 & 0.00 & 0.00 & 4.60 & 0.00 & 0.00 & 0.00 & \\
\hline * 18.85 & 0.00 & 45.45 & 41.66 & 0.00 & 0.00 & 0.00 & 0.00 & 0.00 & 0.00 & 0.00 & 0.00 & 0.00 & \multirow{2}{*}{$\begin{array}{l}\text { Gyrodactylus } \\
\text { elegans }\end{array}$} \\
\hline${ }^{*} 5.02$ & 0.00 & 10.40 & 5.60 & 0.00 & 0.00 & 0.00 & 0.00 & 0.00 & 0.00 & 0.00 & 0.00 & 0.00 & \\
\hline * 21.68 & 63.63 & 36.36 & 0.00 & 0.00 & 0.00 & 0.00 & 0.00 & 0.00 & 0.00 & 0.00 & 0.00 & 0.00 & \multirow{2}{*}{ Dogielius persicus } \\
\hline${ }^{*} 6.33$ & 9.42 & 9.50 & 0.00 & 0.00 & 0.00 & 0.00 & 0.00 & 0.00 & 0.00 & 0.00 & 0.00 & 0.00 & \\
\hline
\end{tabular}


ISSN Onlin:2708-9347, ISSN Print: 2708-9339 Volume 9, Issue 1 (2020) PP 1-12

https://jam.utq.edu.iq/index.php/main Doi: https://doi.org/10.54174/UTJagr.Vo9.N1./01

\begin{tabular}{|c||c||c||c||c||c||c||c||c||c||c||c||c||c||c||c|}
\hline${ }^{*} 17.42$ & 0.00 & 63.63 & 0.00 & 0.00 & 0.00 & 0.00 & 0.00 & 0.00 & 0.00 & 0.00 & 0.00 & 0.00 \\
\hline${ }^{*} 5.18$ & 0.00 & 7.85 & 0.00 & 0.00 & 0.00 & 0.00 & 0.00 & 0.00 & 0.00 & 0.00 & 0.00 & 0.00 \\
\hline${ }^{*} 19.37$ & 0.00 & 54.00 & 0.00 & 0.00 & 0.00 & 0.00 & 0.00 & 0.00 & 0.00 & 0.00 & 0.00 & 0.00 \\
\hline${ }^{*} 4.96$ & 0.00 & 10.66 & 0.00 & 0.00 & 0.00 & 0.00 & 0.00 & 0.00 & 0.00 & 0.00 & 0.00 & 0.00 & Eudtylogyrus \\
nipponicum \\
\hline
\end{tabular}




\section{https://jam.utq.edu.iq/index.php/main $\quad$ Doi: https://doi.org/10.54174/UTJagr.Vo9.N1./01}

Table 3. The incidence and severity of infection in the third station according to the different months of the study

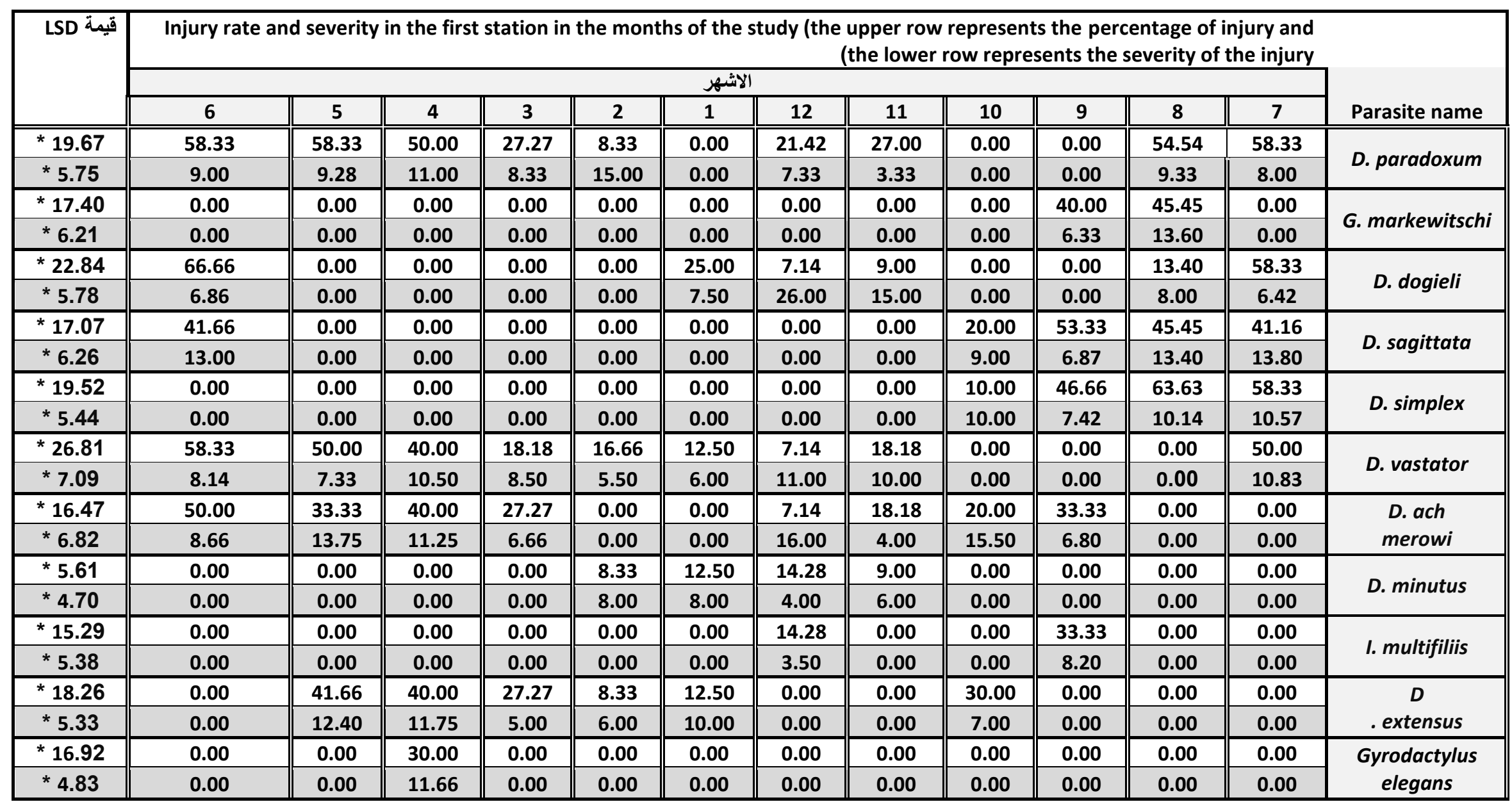


ISSN Onlin:2708-9347, ISSN Print: 2708-9339 Volume 9, Issue 1 (2020) PP 1-12

https://jam.utq.edu.iq/index.php/main Doi: https://doi.org/10.54174/UTJagr.Vo9.N1./01

\begin{tabular}{|c|c|c|c|c|c|c|c|c|c|c|c|c|c|}
\hline * 18.31 & 41.66 & 41.66 & 0.00 & 0.00 & 0.00 & 0.00 & 0.00 & 0.00 & 0.00 & 0.00 & 0.00 & 0.00 & $\begin{array}{c}\text { Dogielius } \\
\text { persicus }\end{array}$ \\
\hline * 17.58 & 50.00 & 33.33 & 0.00 & 0.00 & 0.00 & 0.00 & 0.00 & 0.00 & 0.00 & 0.00 & 0.00 & 0.00 & $\begin{array}{c}\text { Dactylogyrus } \\
\text { arquatus }\end{array}$ \\
\hline${ }^{*} 15.78$ & 0.00 & 41.66 & 0.00 & 0.00 & 0.00 & 0.00 & 0.00 & 0.00 & 0.00 & 0.00 & 0.00 & 0.00 & \multirow{2}{*}{$\begin{array}{l}\text { Eudiplozoon } \\
\text { nipponicum }\end{array}$} \\
\hline${ }^{*} 4.69$ & 0.00 & 11.40 & 0.00 & 0.00 & 0.00 & 0.00 & 0.00 & 0.00 & 0.00 & 0.00 & 0.00 & 0.00 & \\
\hline
\end{tabular}




\section{Refrences}

1 - Abdul Majid, Amana Tariq (2007). Economic analysis of the factors affecting the required quantities of meat Fish in Iraq for the period 1980-2002 Master Thesis. Department of Economics. Faculty of Agriculture. University Baghdad p. 130

2 - Jaber, Amer Abdullah, Yunus Kazem Hassan, Mohamed Hanawa Moussawi (2008). Proceedings of Aquaculture in Maysan Governorate, Iraqi Journal of Aquaculture, Volume (5), No. (2) pp. 51-64.

3. Abimorad, E.G. and Carneiro, D. J. (2007). Digestibility and performance of pacu (Piaractucmesopotamicus) juvenile fed diets containing different protein, lipidand carbohydrates levels. Article first published online: 11, Volume13, Issue1 pages 1-9. (Abstract)

4. Zatif, V. Kiziviter, I. Lachonov, L. Makarova, T. Minder, L. And Podsovalov, in. (1986). Fishery Products Technology, translated by Mazen Jameel Hindi, Basra University Press: 853

5. Secretary, Amin Abdel Wahab (1993). The Iraqi experience of raising fish in Iraqi ponds. Proceedings of the Specialized Scientific Symposium on the Development of Fish Breeding and Optimal Utilization of Water Bodies Baghdad, pp. 1010-1181

6. Al-Shamma, Amer Ali (1993). Fisheries resources in the marshes of southern Iraq and ways of protecting and developing them. Conference of Arab Scientific Research Councils, Baghdad.

7. Al-Humiri, Kazem Obaid Matar (2011). Technical and economic assessment of fish seafarers in Babil Governorate. Master degree, Technical College / Musayyib.

8. Kassam, L, (2011). Aquaculture farmer organizations and cluster management. FAO Fisheries and aquaculture technical paper 563 fao consulatant London, United Kingdom of Great Britiain and Northern Ireland.

9. Sharma, M .; Shrivastav, A. B .; Sahni, Y. P. and Pandy, G. (2012). Overview of the 1treatment and control of common fish diseases. Int. Res. J. Pham., 3 
$123-1271$

10. Al-Malki, G. M .; Al-Khafaji, K. K. and Al-Shemary, A. J. (2015). Incidence of parasites in Tilapia zillii from Tigris at north of Qurna with some (environmental1parameters of the River J. Basrah Res., Sci., 412) A: 86-92

11. Noor El-Deen, A. I .; Abd El Hady, O. K .; Liala, A. M. and Zaki, M. S. (2015). A trial for control of some parasites diseases cultured Orechromis niloticus in Egypt. Life Sci. J., 12 (8): 25-29. .

Eissa, I.A.M. (2002). Parasitic fish diseases in Egypt. Dar El- Nahda El - Arabia Publishing 32 Abd El- KhalekTharwat st. Cairo, Egypt

13. SAS. 2012. Statistical Analysis System, User's Guide. Statistical. Version 9.1th ed. SAS. Inst. Inc. Cary. N.C. USA.

14. Welch, p, s (1948). Limnological methods, McGraw-HillBook CO., Inc., New York: $381 \mathrm{pp}$

15. Kennedy, C, R. (1975). Ecological animal parasitology. Blackwell Sci publ., London: $163 \mathrm{pp}$

16-1Barse, A. M. (1998)> Gill parasites of mummichogs, Fundulus heterolitus (Teleostei: Cyprinodontidae): effects of season, locality, and host sex and size J. PARASITOL., 84 (2): 236-244. 